\title{
Female morphology and systematic status of Philometroides cyprini (Nematoda: Philometridae), a parasite of carp
}

\author{
František Moravec $^{1, *}$, Stanislav Červinka ${ }^{2,3}$ \\ ${ }^{1}$ Institute of Parasitology, Academy of Sciences of the Czech Republic, Branišovská 31, 37005 České Budějovice, \\ Czech Republic \\ ${ }^{2}$ Fishery Technical School, Zátiší 480/2, 38919 Vodňany, Czech Republic \\ ${ }^{3}$ Fishery Educational Establishment, Táboritská 941/II, 37901 Třeboň, Czech Republic
}

\begin{abstract}
Gravid females of Philometroides were found under the scales of stock carp Cyprinus carpio L. imported from Lithuania to the Czech Republic in the spring of 1997 and kept in a quarantine pond. These specimens and those obtained from pond-cultured carp in Russia (Moscow district) were used for detailed morphological studies, including scanning electron microscopy. The results confirm that the valid name of this parasite is Philometroides cyprini (Ishii, 1931), whereas Philometra lusii Vismanis, 1962, Philometra schikhobalowae Belous, 1965, Philometra lusiana Vismanis, 1966 and Philometroides lusiana (Vismanis, 1966) Ivashkin et al., 1971 are its junior synonyms. P. cyprini, the agent of a serious disease of carp, seems to have been originally distributed in east Asia, from where it was introduced into Europe in the early 1960s.
\end{abstract}

KEY WORDS: Parasitic nematode $\cdot$ Philometra $\cdot$ Philometroides cyprini $\cdot$ Philometroides lusiana • Morphology $\cdot$ Cyprinus carpio $\cdot$ Species introduction $\cdot$ Czech Republic

\section{INTRODUCTION}

Vismanis (1962) described a new philometrid species, Philometra lusii, from gravid females found under the scales of common carp Cyprinus carpio L. in Lithuania. However, because of some mistakes in the original description, he later redescribed and reestablished this species and renamed it $P$. lusiana Vismanis, 1996 (see Vismanis 1966). Ivashkin et al. (1971) transferred the species to the genus Philometroides Yamaguti, 1935. This pathogenic nematode has subsequently been reported, mainly from pond-cultured carps, from many areas of Russia (e.g. Kaliningrad [Königsberg] district, Moscow and Smolensk regions), Belarus and Ukraine (Vasilkov 1967, 1968a, Avdeeva \& Evdokimova 2004).

The parasite causes philometroidosis disease of carp, which manifests itself especially in heavily infected fish and may even lead to the death of young carp (Vasilkov 1967, 1983, Kudentsova et al. 1975). Various species of copepods (Copepoda) function as the inter- mediate host, and the life cycle of the parasite in European conditions is annual. Maturation is strictly seasonal; gravid females bearing larvae in the uterus occur only from the end of May until the beginning of June (Vismanis 1964, 1970, Vasilkov 1967, 1968a,b).

In 1976, Nakajima redescribed Philometroides cyprini (Ishii, 1931) from female specimens collected from Cyprinus carpio in Japan. He considered $P$. cyprini to be synonymous with Philometroides lusiana (Vismanis, 1966) Ivashkin et al., 1971 and remarked that the former species had long been known as a common parasite of cultured carp in Japan.

However, Vismanis et al. (1987) did not agree and regarded Philometroides cyprini and Philometroides lusiana as 2 independent species. According to them, females of $P$. lusiana possess 4 cephalic papillae and 4 caudal projections, whereas those of $P$. cyprini have no cephalic papillae and only 2 caudal projections. They considered the specimens studied by Nakajima (1976) to belong to $P$. lusiana and those originally described 
by Ishii (1931) to $P$. cyprini. As a junior synonym of the latter Vismanis et al. (1987) designated Philometra shikhobalowae Belous, 1965, a species established by Belous (1965) from specimens collected from Cyprinus carpio of Lake Khanka (Amur River basin), Russian Far East. Vismanis et al. (1987) argue that Ishii (1931) did not mention any cephalic papillae in the original description of $P$. cyprini and Belous (1965) did not observe cephalic papillae in her specimens, which had 2 caudal projections. It is necessary to remark, however, that the descriptions provided by these 2 authors are inadequate.

Based on literature data and partly on personal observations of specimens, Moravec (1994) followed the conception of Nakajima (1976) and took Philometroides lusiana to be a junior synonym of $P$. cyprini. However, the name $P$. lusiana has been commonly used for this species in the recent Russian parasitological literature (e.g. Avdeeva \& Evdokimova 2004) and in web electronic databases. Moreover Cakić et al. (2002) reported P. lusiana and P. cyprini as 2 distinct species from the abdominal cavity of the Mediterranean barbel Barbus meridionalis Risso, from Yugoslavia.
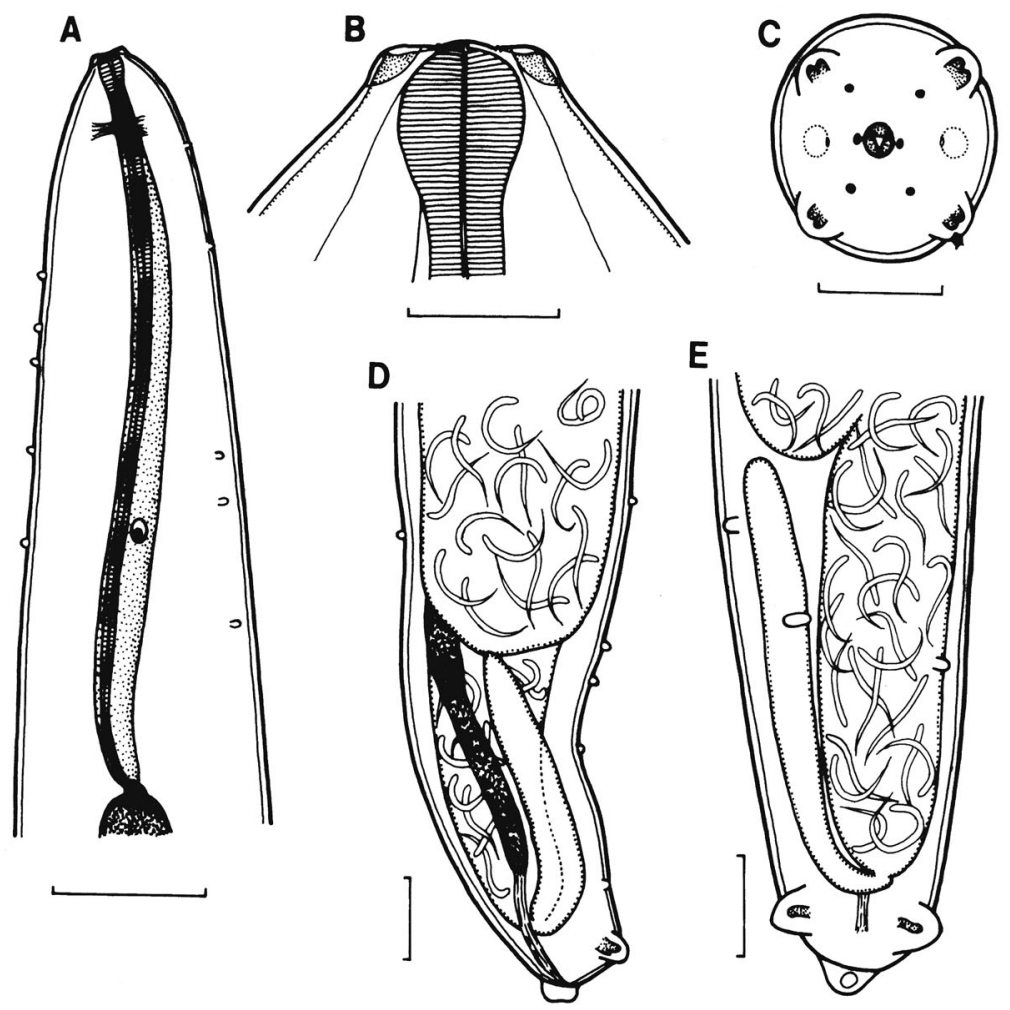

E

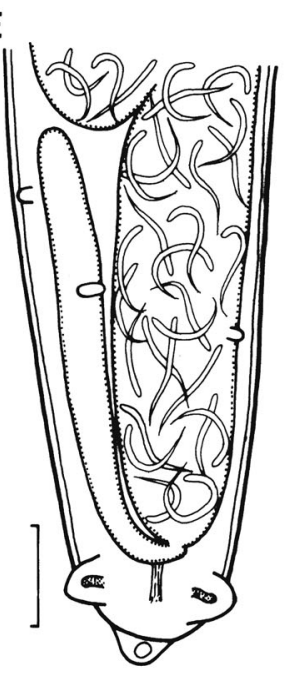

Fig. 1. Philometroides cyprini. (A) Anterior part of subgravid female (lateral view). (B,C) Cephalic end (lateral and apical views). (D,E) Posterior part of gravid female (lateral and dorsal views). Scale bars: $\mathrm{A}=0.5 \mathrm{~mm}$; $\mathrm{B}=0.05 \mathrm{~mm} ; \mathrm{C}=0.1 \mathrm{~mm} ; \mathrm{D}, \mathrm{E}=0.2 \mathrm{~mm}$

\section{MATERIALS AND METHODS}

In the spring of 1997, live stock carp Cyprinus carpio were imported from Lithuania to the Czech Republic by the State Fishery Hluboká nad Vltavou (South Bohemia) and were placed in a quarantine pond (Haklovský pond). During the $30 \mathrm{~d}$ quarantine period, 15 fish were examined to check their health and condition. All fish were infected by gravid Philometroides females located under the scales. Subsequently, the entire fish stock was killed, and the pond was dried out and disinfected in order to eliminate the parasite.

A few of the above mentioned Philometroides specimens and those previously provided by Dr. G. V. Vasilkov (collected from pond-cultured carp at a fish farm in Gzhelka, Moscow district, Russia, in May 1963) were first studied by light microscopy (LM) and scanning electron microscopy (SEM).

The nematodes were fixed in hot $4 \%$ formaldehyde solution in physiological saline and then kept in $4 \%$ formaldehyde solution in water. For LM examination, they were cleared with glycerine. Drawings were made with the aid of a Zeiss drawing attachment. Specimens used for SEM were postfixed in $1 \%$ osmium tetroxide, dehydrated through a graded ethanol series, critical point dried and sputter-coated with gold; they were examined using a JEOL JSM-6300 scanning electron microscope at an accelerating voltage of $15 \mathrm{kV}$.

\section{RESULTS}

The gravid female nematodes were 7.02 to $10.9 \mathrm{~cm}$ long and 843 to $1339 \mu \mathrm{m}$ in maximum width. Live specimens were red; those fixed in $4 \%$ formaldehyde solution in physiological saline were brownish. The body surface was covered with numerous irregularly distributed cuticular bosses (Figs. 1A,D,E \& 2D,F). At the cephalic end there were 4 submedian slightly elevated lobes, each with a pair of small cephalic papillae of the external circle (Figs. 1B,C \& $2 \mathrm{~A}, \mathrm{C}) ; 4$ small single submedian and 2 lateral papillae of the internal circle surrounded the small oral aperture (Figs. 1C \& 2B). The oesophagus was 2.24 to $2.78 \mathrm{~mm}$ long and 122 to $174 \mu \mathrm{m}$ in maximum width, with a moderately developed anterior bulb (Fig. 1B); the oesophageal gland containing a large cell nucleus was well developed. The nerve ring was 218 to $278 \mu \mathrm{m}$ from the anterior extremity. The anus and 

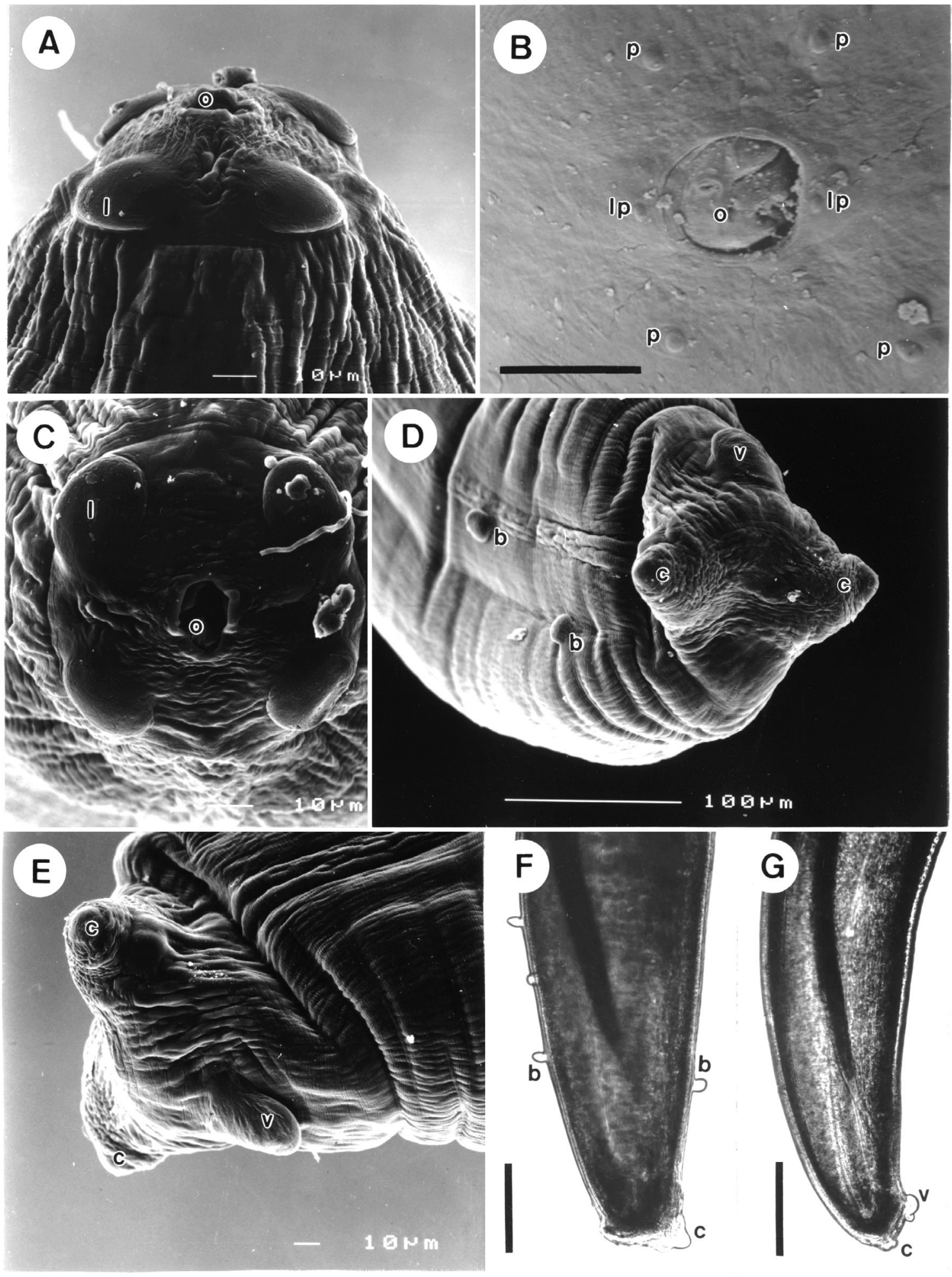

Fig. 2. Philometroides cyprini. (A-E) Scanning electron micrographs of gravid female showing (A,C) cephalic end (lateral and apical views), (B) region of oral aperture (apical view) and (D,E) caudal end (subapical and subventral views). (F,G) Subdorsal and lateral views of the posterior part of the nematode (light microscope). Abbreviations: $\mathrm{b}=$ cuticular boss; $\mathrm{c}=$ dorsolateral caudal projection; 1 = submedian cephalic lobe containing pair of outer papillae; lp = lateral cephalic papilla of inner circle; $\mathrm{o}=$ oral aperture $; \mathrm{p}=$ submedian cephalic papilla of inner circle $; \mathrm{v}=$ ventral caudal cuticular lobe. Scale bars: $\mathrm{A}, \mathrm{C}, \mathrm{E}=10 \mu \mathrm{m} ;$ $\mathrm{B}=30 \mu \mathrm{m} ; \mathrm{D}=100 \mu \mathrm{m} ; \mathrm{F}, \mathrm{G}=500 \mu \mathrm{m}$ 
vulva were atrophied. The posterior end bore 2 large dorsolateral caudal projections $54 \mu \mathrm{m}$ long, sometimes appearing to be doubled inside; a large cuticular lobe was present on the ventral side (Figs. 1D,E \& 2D-G). The uterus was filled with first-stage larvae 383 to $560 \mu \mathrm{m}$ long and 14 to $16 \mu \mathrm{m}$ wide.

\section{DISCUSSION}

Because the cephalic papillae of most philometrids are difficult to observe by LM, these nematodes have sometimes been described as having no such papillae; therefore, the use of SEM is the only reliable means of studying the papillae (Moravec 2004). However, the Philometroides females parasitizing the skin of carp have not been previously studied by SEM, and for the most part their cephalic ends have not been observed by LM in an apical view. In fact, the 4 'papillae' reported in these nematodes by Vismanis (1966) and Nakajima (1976) are the submedian cephalic lobe-like elevations, each with a pair of small, submerged papillae of the external circle. As confirmed in this study, these elevations may be only poorly developed in some specimens and, consequently, difficult to observe. The papillae of the internal circle have not been observed at all by previous authors. The number and arrangement of cephalic papillae as found in this study is typical of many other philometrid species (Moravec 2004).

As confirmed by SEM, the posterior end of these female nematodes bears 2 caudal projections, as in the majority of other philometrid species in which these are present. According to Vismanis (1966), there are 2 smaller lateral projections of cuticular character present between the large caudal projections. However, in a later study (Vismanis 1967) he illustrated the caudal end bearing, in addition to the 2 large simple lateral caudal projections, a large ventral and a smaller dorsal projection. The present study has revealed the double inner structure of the dorsolateral caudal projection and the presence of a large ventral cuticular projection (see also Moravec 1994).

We have shown that the differences in descriptions of Philometroides cyprini and P. lusiana arose due to insufficient knowledge of the morphology of these nematodes and that both species are identical. The valid name is Philometroides cyprini, whereas Philometra lusii, Philometra schikhobalowae, Philometra lusiana and Philometroides lusiana are its junior synonyms.

It can be assumed that Philometroides cyprini was originally distributed in east Asia - with reports of the species occurrence in Japan (Ishii 1916, 1931), China (Chen 1973, Pan et al. 1990) and in the Russian Far East (Belous 1965) - and that it was introduced from there into Europe in the 1960s.
Acknowledgements. The authors thank the staff of the Laboratory of Electron Microscopy, Institute of Parasitology, ASCR, in České Budějovice for their technical assistance, and Irena Husáková, a technician of the Department of Helminthology of the same Institute, for her help with illustrations. P. cyprini specimens were kindly provided in part by the late Dr. G. V. Vasilkov, VIGIS, Moscow. This study was supported by grant no. 524/03/0061 from the Grant Agency of the Czech Republic and the research project of the Institute of Parasitology, ASCR (no. Z60220518).

\section{LITERATURE CITED}

Avdeeva EV, Evdokimova EB (2004) Results of ecologicalparasitological study of fishes of some reservoirs in Kaliningrad District: an overview. In: Nigmatullin ChM (ed) Modern problems of parasitology, zoology and ecology. KGTU Press, Kaliningrad, p 188-200 (in Russian with English abstract)

Belous EV (1965) Nematodes of freshwater fishes of the Primorsk Territory. In: Parasitic worms of domestic and wild animals. Vladivostok, p 48-65 (in Russian)

Cakić P, Stojanovski SS, Petrović Z, Lenhard M, Fister S (2002) The first record of parasite nematode genus Philometroides in Yugoslav freshwater fish. Exp Pathol Parasitol 5/8:3-6

Chen CL (ed) (1973) An illustrated guide to the fish diseases and causative pathogenic fauna and flora in the Hubei Province. Science Press, Beijing (in Chinese)

Ishii S (1916) Observations on filariasis of carp. Rep Fish Inst 12:14-24 (in Japanese)

Ishii S (1931) Parasites of fishes of Japan. In: Iwanami (ed) Biology, Pt. 18, p 179-207 (in Japanese)

Ivashkin VM, Sobolev AA, Khromova LA (1971) Camallanata of animals and man and the diseases caused by them. Essentials of nematology, 22. Nauka, Moscow (in Russian)

Kudentsova RA, Chernysheva NB, Gershkovich BD (1975) Receptivity of different breeding groups of carp to philometroidosis. Rybokhozyaistvennoe izuchenie vnutrennykh vodoemov, Sbor. GosNIORKh (Fishery study of inland basins, Collective papers of GosNIORKh), No. 15, p 66-68 (in Russian)

Moravec F (1994) Parasitic nematodes of freshwater fishes of Europe. Academia and Kluwer Academic Publishers, Praha and Dordrecht

Moravec F (2004) Some aspects of the taxonomy and biology of dracunculoid nematodes parasitic in fishes: a review. Folia Parasitol 51:1-13

Nakajima K (1976) Synonym of Philometroides cyprini (Ishii). Fish Pathol 11:97-99 (in Japanese with English abstract)

Pan JH, Zhang JY, Li ZC (eds) (1990) Fish parasitology. Science Press, Beijing (in Chinese)

Vasilkov GV (1967) Philometrosis of carp. Veterinariya 1: 62-64 (in Russian)

Vasilkov GV (1968a) On the recognition of the developmental cycle of Philometra lusiana (Nematoda, Dracunculidae), a parasite of carp. Dokl Vses ordena Lenina Akad S-kh Nauk im V I Lenina 12:28-30 (in Russian)

Vasilkov GV (1968b) Contribution a l'étude de la Philométrose des carpes. Bull Off Int Epiz 69:1193-1196

Vasilkov GV (1983) Helminthoses of fishes. Kolos, Moscow (in Russian)

Vismanis KO (1962) Philometrosis of carp in pond farms of the Lithuanian SSR. Izv AN LatvSSR, Riga (Reports of the Lithuanian SSR) 4:93-96 (in Russian) 
Vismanis KO (1964) On the biology of Philometra lusii Visman. Vopr Ikhtiol 4:192-193 (in Russian)

Vismanis KO (1966) Study of the agent of philometrosis in carp. In: Symp Parasites Dis Fish Aquat Invertebr, Abstracts. Nauka, Moscow - Leningrad, p 9-10 (in Russian)

Vismanis KO (1967) On the morphology of Philometra lusiana Visman nom. nov. (Nematoda: Dracunculidae). Zool Zh 46:759-761 (in Russian)

Editorial responsibility: Wolfgang Körting,

Hannover, Germany
Vismanis KO (1970) Life cycle of the agent of philometrosis of carp. Tr Baltiysk NII Ryb Khoz (Papers of the Baltic Fishery Research Institute) 4:403-415 (in Russian)

Vismanis KO, Lomakin VV, Roytman VD, Semanova MK, Trofimenko VYa (1987) Phylum Nemathelminthes. In: Bauer ON (ed) Key to parasites of freshwater fishes of the USSR fauna, Vol 3. Parasitic metazoans, Pt 2. Nauka, Leningrad, p 199-310 (in Russian)

Submitted: March 4, 2005; Accepted: May 18, 2005

Proofs received from author(s): September 29, 2005 